\title{
A Light in Students' Lives: K-12 Teachers' Experiences (Re)Building Caring Relationships During Remote Learning
}

\author{
Karyn E. Miller \\ Texas A\&M University-Commerce
}

\begin{abstract}
This study illuminates the experiences of K-12 educators as they strove to (re)build caring relationships with students during the COVID-19 pandemic. The study was conducted during a graduate course for experienced K-12 teachers in the spring of 2020 at a four-year comprehensive university in the United States. Data was collected from reflective learning journals and asynchronous peer discussions, which captured educators' experiences as they transitioned to remote learning in real-time. Qualitative content analysis was used to identify pertinent themes. Findings suggest that remote learning revealed relationships in need of repair. Educators practiced authentic care and cultivated connectedness by (a) acting as warm demanders, (b) responding to students' social-emotional needs, and (c) trying to bridge the digital divide. The article concludes with implications for practice and areas for future research as schools, districts, states, and countries consider the "new normal" in K-12 schooling.
\end{abstract}

Keywords: care in education, school belonging, connectedness, remote learning, online learning communities, K-12 schooling

Miller, K.E. (2021). A light in students' lives: K-12 teachers' experiences (re)building caring relationships during remote learning. Online Learning, 25(1), 115-134. https://doi.org/10.24059/olj.v25i1.2486

\section{A Light in Students' Lives:}

\section{K-12 Teachers' Experiences (Re)Building Caring Relationships During Remote Learning}

School connectedness is the extent to which "students feel attached to at least one caring and responsible adult at school" (Cohen, McCabe, Michelli, \& Pickeral, 2009, p. 185). Caring teacher-student relationships help students "feel accepted, liked and connected to others" (OECD, 2019, p. 130), and support students' perseverance and attainment (Kotok, Ikoma, \& Bodovski, 2016). When students' basic needs for care and belonging are met (Dreikurs \& Cassel, 1972; Glasser, 1998, Maslow, 1962), they are more willing to learn and are more successful academically and personally (Cohen et al., 2009; Glasser, 1998; Osterman, 2000; Resnick et al., 1997). Yet, 
evidence suggests a troubling decline in school connectedness over the past 15 years (OECD, 2017). Recent PISA data indicates that one in five 15-year-olds feel like an outsider at school, while one in six feels lonely; the proportion of students in the United States who feel isolated is even higher (OECD, 2019).

When the coronavirus pandemic abruptly closed K-12 schools worldwide, the transition to remote learning threatened to exacerbate this problem. In the online environment, "there is a greater possibility for a sense of loss among learners - loss of contact, loss of connection, and a resultant sense of isolation" (Palloff \& Pratt, 2007, p. 31). Students' self-reports of increased anxiety and depression during the pandemic may, in part, reflect these losses and the broader effects of social isolation (Jones, 2020). While attention has focused on schools' struggles to provide quality instruction and close the technology gap (Dorn, Hancock, Sarakatsannis, \& Viruleg, 2020), limited research has examined how schools addressed students' social and emotional needs for care and connection amid the pandemic. This study investigates this understudied area by illuminating educators' voices as they confronted the challenge of (re)building caring relationships remotely during the spring of 2020.

The article is organized into four sections. The first section introduces the ethics of care as a framework for the study and reviews the theoretical and empirical research on caring relationships in schools. The second section describes the qualitative methodology used to examine the research questions. The third section presents findings thematically. The final section discusses the results in light of the existing research on caring online learning communities and concludes with implications for practice and further research.

\section{Review of Relevant Literature}

\section{The Ethics of Care: A Relational Approach to Schooling}

Care ethicists have long argued that caring is relational (Gilligan, 1993; Noddings, 1984, 2002). Gilligan (1993) states that care is the act of building social bonds so that "no one is left alone" (p. 62), serving to increase belonging and enhance life (Noddings, 2005). Caring relationships consist of the carer, the individual providing care, and the cared-for; each has a role in developing the relational bond (Noddings, 2002). As a practice, caring requires effort, primarily from the person providing the care (Held, 2006). The carer must see the needs of the cared-for and "respond as positively as possible" (Gilligan, 1993; Noddings, 2005, p. xiv). The cared-for, in turn, must acknowledge receipt of the care. This perspective approaches caring as reciprocal; in a caring relationship, there is a feedback loop between the carer and cared-for (Noddings, 2002).

In the school setting, the teacher is always the carer, the students the cared-for (Noddings, 2005; Noddings, 2012). "Authentic care" (Valenzuela, 1999) in education is labor-intensive and requires teachers to move beyond building superficial rapport, acting "nice," or being permissive in order to meet students' needs (Noddings, 2007; Ransom, 2020). Caring teachers engage students in dialogue about their interests and needs, listen attentively, and express empathy (Noddings, 1984, 2005; Osterman, 2010). Teachers further demonstrate authentic care by using positive and respectful communication (Ginot, 1972; Marshall, 2012), fostering peer discussion and interactions (Keyes, 2019; Osterman, 2010; St-Amand, Girard, \& Smith, 2017), and using a familial approach to maximize each student's potential (Pang, Rivera, \& Mora, 2000). 
Authentic care practices are characterized by trust. When students "trust those who care for them," they can "develop well and flourish" (Held, 2006, p. 42). Although the development of deep relationships with all students may be unfeasible, caring teachers are present with their students even in brief moments of interaction (Noddings, 1984). Authentically caring schools prioritize relational bonds and embrace relationship-building as an institutional value (Ancess, 2008; Tichnor-Wagner \& Allen, 2016).

\section{Challenges to Authentic Care and Belonging in Schools}

The relational bonds that grow from authentic care are vital to students' sense of belonging (Allen, Kern, Vella-Brodrick, Hattie, \& Waters, 2018; Keyes, 2019; Osterman, 2000; Riley, 2019; St-Amand et al., 2017; Wang \& Eccles, 2012). However, Noddings (2005) observes that, "in many of our schools today, we find teachers are trying to care and students who want to be cared for, and yet many of those students claim, 'Nobody cares!' (p. xv). This observation suggests that students' decreased sense of school connectedness may correspond with (a) eroding authentic care in schools or (b) students' perceptions of diminished care.

As neoliberal education rhetoric has informed education policy decisions, most strikingly the emphasis on high-stakes accountability testing, schools have shifted away from a relational approach to one driven by testing performance, school ratings, and maintaining or improving their position in the education marketplace (Lewis \& Pearce, 2020). Accountability policies that privilege rigid curriculum and standardized assessment measures have narrowed student preparation to testing in reading, math, and science (Noddings, 2005). Within this context, it is difficult for teachers to find time to attend to students' needs responsively and develop relationships, even when they desire to do so (Ancess, 2008; Cooper, 2004; Noddings, 2007).

Under these conditions, some teachers view their role as builders of knowledge and skills rather than relationship-builders (Ransom, 2020). In lieu of a relational approach, teachers may use "boss management" approaches that overlook students' needs, and are often coercive and punitive, to achieve their ends (Glasser, 1990). Boss management and hyper-attention to test scores are especially detrimental to academically struggling students, for whom caring relational bonds are critical (Carter, 2012). However, low-performing urban schools, which are disproportionately attended by low-income students of color, are less likely than high-performing urban schools to exhibit a school-wide culture of care (Tichnor-Wagner \& Allen, 2016).

Despite the schooling climate created by neoliberal education policies, Noddings (2005) observes, "in an important sense, teachers do care, but they are unable to make the connections that would complete caring relations with their students" (p. 2). Thus, teachers may value care, and believe they are demonstrating responsive care, but students may not recognize the care as such. This disconnect can be especially fraught and influenced by distrust when there is a cultural mismatch between teachers and students (Davis, 2003). Culturally responsive modes of relational care account for students' cultural perspectives and acknowledge the needs of culturally diverse students (Antrop-Gonzalez \& De Jesus, 2006; Gay, 2018). For example, successful teachers of students of color often assume the role of "warm demander" where a positive attitude accompanies an insistence on high expectations (Vasquez, 1989); Ware (2006) describes this approach as reflective of a culturally responsive ethics of care. 


\section{Relational Bonds Online and the Digital Divide}

With the growth of online interactions, scholars have extended the ethics of care beyond face-to-face interactions (Held, 2006) to online learning (Robinson, Kilgore, \& Warren, 2017). Mastel-Smith, Post, and Lake (2015) introduce the term "online caring presence" to describe how nursing faculty perceive their role as carers in online learning communities. Online instructors describe fostering relational bonds by instilling confidence through positive affirmation and feedback, using group work to increase peer interaction, and providing opportunities for all community members to share personal information, preferably in a synchronous manner (Berry, 2019; Mastel-Smith et al., 2015).

Teachers in K-12 online settings similarly perceive that their active involvement in the online learning environment is vital to building a strong community (Garret Dikkers, Whiteside, \& Lewis, 2013). Velasquez, Graham, \& West (2013) find that caring teachers initiate dialogue with students, converse with them about academic and personal issues, and demonstrate an interest in students' overall well-being. They often reach out to students to check progress and offer help (Borup, Graham, \& Velasquez, 2013; Borup, Graham, \& Drysdale, 2014). Using an ethics of care framework to study technology-mediated care at an online high school, Velasquez, Graham, and Osguthorpe (2013) argue that teachers' responsiveness to students' needs requires understanding their technology preferences and preferred forms of communication, such as chat and text messaging (Berry, 2019; Borup, Walters, \& Call-Cummings, 2020; Garret Dikkers et al., 2013; Velasquez, Graham, \& Osguthorpe, 2013). In turn, online K-12 students report that caring relationships with teachers and sustained interactions strongly influence their success (Borup \& Stevens, 2017).

Research on the digital divide has raised concerns about who can access and participate in online learning communities. The first level of the digital divide is basic access to the hardware and internet connectivity required for online participation (Resta, Laferrière, McLaughlin, \& Kouraogo, 2018). Rural, low-income, and Black and Latino students are more likely to experience challenges with access than their urban, affluent, and white peers (Cleary, Pierce, \& Trauth, 2005; NTIA, 2014). Although concern has shifted to considerations of differences in technology use and skills (Ritzhaupt, 2013), evidence suggests the fundamental issue of access remains a significant challenge for many students (Resta et al., 2018).

\section{Research Question}

This study considers the extent to which teachers' responses to remote learning reflect authentic caring practices and whether educators' actions during this time can offer fresh insight into crafting communities of care in education. This study explores the following questions:

- What did the transition to remote learning reveal about educators' existing relationships with students?

- How did educators establish and/or maintain caring relational bonds with students during remote learning? 


\section{Methods}

This qualitative study is part of a larger action research project that explores the value of self and shared reflection in graduate teacher education. It was conducted during the spring of 2020 at a four-year comprehensive university in the southern region of the United States in an online asynchronous graduate course for certified, experienced K-12 teachers. The purpose of the course was to critically examine how to create the best learning environment for students. When K-12 schools closed halfway through the semester, the study provided a unique opportunity to investigate "how people are experiencing an event" (Agee, 2009, p. 434), the unprecedented transition to remote learning, through participants' individual and collective reflection on their own classroom management practices.

\section{Course Participants}

The course was composed of twenty graduate students, nineteen of whom were women (95\%). All course participants taught in an elementary $(65 \%)$ or secondary $(35 \%)$ school setting, and had a least one year of teaching experience, with $95 \%$ teaching during the spring 2020 semester. The majority taught in a large metropolitan area in the same region as the university, and the remainder taught in surrounding suburban or rural counties. Almost all (95\%) taught in public schools, including $65 \%$ who taught in Title I-designated schools, which receive additional federal funds to serve a large concentration of low-income students; three of these teachers specialized in bilingual instruction. While course participants were not explicitly asked to provide additional information about length of teaching experience beyond the one-year minimum, most $(80 \%)$ volunteered this information during class discussions; across these students, the mean years of teaching experience was seven years. Several of the participants were instructional coaches; thus, the inclusive term "educators" is used throughout the presentation of findings.

\section{Data Collection}

Documents, in the form of reflective learning journals and discussion forum posts, were collected at four times throughout the semester, including two occasions prior to the COVID-19 shutdown and two occasions afterward. Course participants used learning journals to connect course readings to their experience and reflect on their teaching practice; they completed one entry per assigned reading during each of the four modules. They engaged in shared reflection four times during the semester by uploading one journal entry of choice to an asynchronous peer discussion forum. While participants were not required to do so, many of them recorded their experiences with remote learning. Their journals and discussions provide a unique insight into educators' reactions and experiences as the COVID-19 pandemic and subsequent school closures unfolded.

After the semester, journals and discussions were downloaded and de-identified per IRB protocol. Data collection resulted in 77 journals, with 251 unique entries, and 2 discussion forums containing 80 discussion threads. About half of these data captured the pre-COVID period, and half captured the period immediately after the first COVID-19 shutdown, as teachers transitioned their own face-to-face K-12 courses to remote learning. The latter set included 37 journals, with 185 individual entries, and 2 discussion forums containing 38 discussion threads.

\section{Data Analysis}

Qualitative content analysis brought "bring meaning, structure, and order to data" (Anfara, Brown, \& Mangione, 2002, p. 31). Analysis followed a multistage coding process. Following steps outlined by Bowen (2009), the first read-through of the documents was used to identify passages 
related to the research questions. The second stage involved chunking and categorizing relevant passages (Anfara et al., 2002; Vaismoradi, Jones, Turunen \& Snelgrov, 2016). This stage was a deductive and inductive process; the literature review provided guidance for expected codes, while open-coding allowed for new codes and categories. Table 1 provides the final coding framework. A separate document kept track of category labels, data, and origin codes for each unit of analysis, an electronic version of the "cutting and sorting" process described by Ryan \& Bernard (2003). Subsequent rereadings helped to refine categories and identify previously overlooked passages. Later stages of data analysis included "winnowing" the data or discarding information and categories irrelevant to the research focus (Creswell, 2013). Through multiple rereadings, coding of recurring concepts into categories, careful examination of the categories, and a focusing of the research questions, pertinent themes emerged.

The process of scrubbing all documents of personally identifying information before analysis rendered it impossible to track changes in individuals' experiences or reflections over time or analyze data by particular characteristics of the course participants. The documents, not the course participants, were the unit of analysis. Finally, quantitative content analysis of the shared reflection discussions offers a high-level overview of the data. Keyword counts provide insight into how frequently specific terms related to the research questions were brought up in discussion and supplement the document analysis.

\section{Table 1}

Coding Framework

\begin{tabular}{|c|c|c|c|c|}
\hline \multirow{2}{*}{$\begin{array}{c}\begin{array}{c}\text { Research } \\
\text { Questions }\end{array} \\
\text { Themes }\end{array}$} & \multicolumn{2}{|c|}{$\begin{array}{c}\text { Existing } \\
\text { Relationships }\end{array}$} & \multicolumn{2}{|c|}{$\begin{array}{c}\text { Relationships during } \\
\text { Remote Learning }\end{array}$} \\
\hline & $\begin{array}{c}\text { Value of } \\
\text { Relationships }\end{array}$ & $\begin{array}{l}\text { Relations in } \\
\text { Need of Repair }\end{array}$ & $\begin{array}{l}\text { Authentic Care } \\
\text { Practices }\end{array}$ & Digital Divide \\
\hline $\begin{array}{c}\text { Classification } \\
\text { Codes }\end{array}$ & $\begin{array}{l}\text { Value of } \\
\text { authentic care } \\
\text { Forms of care }\end{array}$ & $\begin{array}{l}\text { Boss mentality } \\
\text { Unmet needs } \\
\text { Lack of } \\
\text { sustained efforts } \\
\text { Curricular } \\
\text { demands }\end{array}$ & $\begin{array}{l}\text { Accessibility } \\
\text { Culturally responsive } \\
\text { care (warm demander) } \\
\text { Parent involvement } \\
\text { Personal support } \\
\text { Positive } \\
\text { communication } \\
\text { Respect } \\
\text { Student-student } \\
\text { interaction } \\
\text { Student well-being } \\
\text { Synchronous } \\
\text { communication } \\
\text { Teacher-student } \\
\text { dialogue } \\
\text { Technology } \\
\text { preferences }\end{array}$ & $\begin{array}{l}\text { Access Challenges } \\
\text { Student internet } \\
\text { access } \\
\text { Student hardware } \\
\text { Teacher internet } \\
\text { access } \\
\text { Solutions } \\
\text { Mail } \\
\text { communication } \\
\text { Phone } \\
\text { communication } \\
\text { Text } \\
\text { communication }\end{array}$ \\
\hline
\end{tabular}




\section{Results}

Table 2 provides an overview of the frequency with which keywords appeared in the discussion forums throughout the semester. Findings indicate that relational bonds and authentic care were at the forefront of educators' concerns before and during the transition to remote learning. While keyword frequency was reasonably consistent throughout the semester, discussion of student and peer interactions increased after the transition to remote learning (18 repetitions) relative to earlier in the semester ( 7 repetitions), while mentions of connectedness doubled (31 repetitions relative to 16). While educators emphasized the value of relationships with students throughout the spring of 2020, educators' concerns about students' social-emotional needs and maintaining connections grew as they transitioned to remote learning. Discussion of parental involvement also increased during this period, but a robust analysis of those results is beyond the scope of this study.

\section{Table 2}

Word Frequency Table of Keyword Repetition in Shared Reflection Documents

\begin{tabular}{llll}
\hline Keyword & Pretransition & Posttransition & Total \\
Students' needs/ interests & 73 & 51 & 124 \\
Relationships & 66 & 29 & 95 \\
Positive (community, & 44 & 24 & 68 \\
communication, relationships) & & & \\
Parent/parental involvement & 17 & 43 & 60 \\
Connectedness & 16 & 31 & 47 \\
Respect/trust & 41 & 17 & 58 \\
Personal support & 6 & 14 & 20 \\
Peer interactions & 7 & 18 & 25 \\
Care/caring & 14 & 2 & 16 \\
\hline
\end{tabular}

Findings from qualitative content analysis suggest that remote learning unveiled (a) a need to repair and (re)prioritize teacher-student relationships, (b) educators' efforts to re(connect) with students by using authentic care practices, and (c) challenges to relationship building due to the digital divide.

\section{Relational Bonds in Need of Repair and (Re)Prioritization}

Prior to COVID-related school closures, data analysis revealed that educators recognized the value of building relationships with students. Educators reflected on the importance of establishing trust and respect with students to build a nurturing learning environment:

If a child doesn't like or respect you, they are unlikely to learn from you. Isn't that true with us, as adults? If I feel threatened, intimidated, or just downright disrespected, I would find it difficult to focus on the desired outcome of a lesson. It is our job to give our students the tools they need to cope with emotions and minor infractions, not to belittle them and harp on their mistakes.

Educators described relational bonds as being necessary for academic as well as personal success: 
When students realize the teacher truly values and respects them, they see instruction and corrections as they are intended to be-tools to facilitate growth and the acquisition of new skills. I strive to be there for each of my students...because my students know I genuinely care for them and want to help them grow, they succeed academically and behaviorally when these strides might not have been met without this relationship.

Not only did educators describe the value of establishing relationships with students, but they also reflected on various care practices they used to build relational bonds. Establishing relationships requires, "getting to know the student, showing interest in their activities, background, etc...." One educator described using surveys to learn more about her students:

I make a habit of asking students to complete a variety of different student interest surveys throughout the school year to help me stay informed about them. I also use those surveys to help with planning instruction, because I can use something they're interested in to make the lesson relevant to them or their home life. When students realize I have read their responses, they feel valued.

Others described meeting students every morning at the classroom door to have a brief, but attentive, dialogue:

I feel that it sets a positive mood for both me and my students. I usually don't have a problem if they greet their friends as they are coming in as well. I believe that good relationships and communication among them is very important. We get to chat a little and I feel that my students really enjoy having those few minutes to talk to me about anything. I think we all need to start the day off positively.

I also noticed through [greeting students at the door] that not only did my relationship with my students change, but the positive relationship I have with students in the whole grade level changed. Students in my partner teacher's classes improved, I have been more able to relate to them and start their day off on a more calm and respectful note.

In their reflections, educators shared other care practices, such as the "two by ten [approach] where you spend two minutes a day for ten days just talking with the student about whatever interests them," "displaying expectations" and enforcing them "in a respectful manner," and helping students "learn to respectfully exchange information, feelings, and ideas."

Despite their high regard for a relational approach, educators did not necessarily establish relational bonds with students before the transition to remote learning. In part, challenges to fostering relationships with students stemmed from early training that emphasized an authoritarian boss-style approach to classroom management:

'Become the HULK,' is something my instructional facilitator would often tell us as first year teachers. Intimidation and threats to call parents for minor infractions was something they pushed the first couple weeks of school.

Similarly, another educator reflected that, "I struggled my first year with being a boss of my students. I didn't understand the complexities of classroom management and building relationships with the students." It took time for some educators to unlearn these behaviors and foster relationships instead, particularly for those who worked in schools that did not embrace a culture 
of care. They described it taking years of experience, "5 years" or "9 years," for example, to retool their approach and genuinely demonstrate care by "being there" for students.

Some educators in this study struggled to create sustainable caring relationships over time:

I feel very comfortable with the idea of encouraging good behavior by building strong relationships and showing students that I care. However, I struggle with what to do once they have an issue, like frequent outbursts or disruptive behaviors. Once it gets to that point, I am at a loss. I also struggle to motivate students. I was motivated in school, and never understood students who didn't care.

I have students right now that I struggled with at the beginning of the year, so I focused heavily on our relationships. Things got better and negative behaviors decreased for a while, but since winter break, behaviors are worse than ever. This has been true for every teacher these students come into contact with this year.

These reflections reveal educators' sense of frustration with the outcome of their relational efforts. Additional analysis indicates that educators felt a lack of student respect, particularly among secondary students, and a "negativity that so many students already have for us."

As educators transitioned to remote learning, one observed, "I am finding these relationships to be more important than ever...[because] students must be motivated to participate." The context of remote learning helped some educators identify existing weaknesses in student relationships and possible causes. One educator conceded, "I stop really getting to know my kids after the first few weeks of school...the academic part takes over and I let some of the fostering of those relationships go by the wayside." Likewise, another educator expressed the time challenges of maintaining relationships while meeting curricular demands,

I need to make the time to find out the reasons for these [behavioral] issues and deal with them. I would be better prepared to put continued structures in place if I would veer from the curriculum just a bit and spend time building better relationships with my students.

Reflections revealed educators' perceptions that initial rapport-building exercises do not go far enough to establish relational bonds:

I fall short of [building relationships] throughout the progress of the school year. It is something that must be practiced regularly and built upon. Yes, we all do the first day getting to know you games and icebreakers, but then we just stop. We do not foster the progression of these relationships with our students or for our students within the classroom.

In addition, educators observed that cultural mismatches contributed to a lack of connectedness at their schools. One wrote, "teachers [at my school] are too quick to judge students based on their backgrounds and they don't take the time to get to know their students." Another educator noted, "I teach in a very culturally diverse district where it is very common for some teachers to be biased based on students' cultural backgrounds." Several educators reflected on the cultural divide with their own students, acknowledging that, "I realize my background is vastly different from that of my students." Another educator expanded on the difference: 
I come from a very sheltered upbringing with limited cross-cultural experiences. My diverse interactions come from teaching at a Title I campus. My students and their families are culturally, linguistically, and ethnically diverse; they also come from a different socioeconomic status than I do.

One educator observed that, moving forward, she needed to place a higher value on learning about, "students' cultural backgrounds and life experiences, prior knowledge and skills, and areas of interests." As educators struggled to engage and motivate students during remote learning, the pandemic served as a reminder that "relationships need to be built, repaired, and maintained."

\section{Authentic Care and a Relational Approach to Remote Learning}

\section{Positivity \& Warm Demanders}

As courses transitioned to remote learning, educators quickly identified their demeanor as a crucial element in their relational approach to remote learning. One educator wrote, "I aim to be a 'light' in their daily life, instead of something they dread," and another noted that, to create a more enjoyable environment for students, "it is important that I keep a positive point of view, especially while remote teaching." By exuding positivity, educators sought to create a space where students felt cared for and connected.

As the guiding light, educators provided direction in the murky waters of remote learning. Primarily, they did so by (re)establishing their unwavering commitment to student success. As one educator wrote, "[remote learning] has definitely been a challenge to both teachers and students. However, I want to make sure that students continue to try their best and be successful." Educators monitored student participation carefully, making note of which students were completing assignments and who was falling behind. One educator described acting as a warm demander and using weekly phone calls to each student to personalize care, enforce expectations, and support students who were struggling to complete assignments:

Making the weekly calls...allow[s] me to be in contact with the students and make them accountable for their work even though they are not physically in school....[For students who are not completing work,] I will be able to address the issue and guide them in understanding the reason behind the assignments and that I am not willing to let them avoid completing them....I also believe that this will help students see that I care for them and their educational success.

As warm demanders, educators provided academic support tailored to the online learning environment. Another educator described having students reflect weekly on their time usage as a strategy to foster responsible behavior and help students develop the necessary habits to be successful in the online environment:

The best usage of time is a necessary behavior for online class. There is one student in particular that I started a conversation with about [what] he felt was the best usage of his time and why. I asked him to reflect on this week and what he felt could have aided him in accomplishing his work. He realized that he did not feel compelled to complete anything because we were not in class and therefore, he felt everything was optional. We talked about the discipline required of soccer players. [I asked him] if he thought they wanted to practice, eat right, and work together with the same group of people all the time. His love of soccer made him reflect differently. His reflection then turned to his behavior choices. 
By engaging in teacher-student dialogue, this educator realized that some students were struggling to navigate the freedom offered by the new online medium. By communicating with this student personally, making connections between his personal interests and scholastic endeavors, and reflecting on existing habits, he helped this student engage in the remote learning community. Afterwards, the student reallocated his time and started completing assignments. By positively, yet firmly, insisting that students participate and complete the work, educators placed student success at the forefront of their efforts to build relationships based on clear goals and expectations.

\section{Responsiveness to Students' Social-Emotional Needs}

Remote learning brought a respite from a relentless focus on getting through the required curriculum necessary for test preparation. As a result, educators were able to take time to recognize that some students expressed "a sense of being overwhelmed," and modify their academic expectations and personal care accordingly:

Learning from home is particularly challenging for my students, as they feel like they are doing endless busywork. I have been trying to review concepts that they learned throughout the school year, instead of challenging them to learn entirely new content online.

While most of the educators in the study continued to set high expectations for students' academic engagement and performance, they also voiced concern for their students' overall well-being. Educators at Title I schools, in particular, expressed some version of the sentiment that "many of my students come from low socioeconomic families. I worry about them, but not just their schoolwork." As they sought to build and maintain relationships, educators displayed understanding of and compassion for students' needs beyond the academic, and provided opportunities for dialogue with students:

I've gone from seeing 86 beautiful faces everyday to sending out emails and digital lessons. I hold virtual office hours in case anyone needs help, but most show up just to talk and have human interactions. And you know what? I'm okay with that. I'm still meeting the needs of my students. Their social emotional needs are just as important.

During the pandemic, students needed teachers to express care for them and to recognize their unmet needs. Although this educator originally intended to provide academic support during office hours, the purpose largely shifted as students expressed a need just to talk and connect.

Peer connection was equally important. Observing that, "during this time of distance learning for our students, I have heard many of the students express they miss their classmates and friends from school," educators responded to students' need for connection in myriad ways. After initially taking a less interactive approach to their remote learning environment, an educator reflected:

This week, I have decided to change things up in my Google Classroom and bring in more interaction and motivation. My plan is to do a lot more interactive activities as a whole, doing a live meet instead of just assigning and recording myself. I want to provide support, just as if we were in the real classroom. Although I am teaching them online, I still want to establish a 'learning environment.' I want the students to feel supported and encouraged to learn. 
In addition to live meetings, educators incorporated activities such as "live interactive read aloud[s]," "show-and-tell," and "a daily [writing prompt that encourages] a guided conversation similar to what would have been shared in a community circle meeting" into their weekly schedules so that all classroom community members could engage in discussion and share aspects of their personal lives. Educators further attempted to stay involved with their students, motivate student engagement, and provide personal affirmation by hosting "video meetings with my students and [having] conversations with them...in an effort to know about their interests," "doing live chats or sending motivational messages," as well as "sending personalized letters home and giving "shout outs" on Seesaw." Additionally, one educator mentioned using weekly phone calls with students to, "support the students with their emotional state and encourage them to continue to learn." Although some remote learning environments, particularly in the early days of the COVID-19 crisis, may have lacked opportunities for social interaction, the educators in this study were keenly aware of both the motivational value and social-emotional benefits of continuing to build relationships with and between students.

\section{Bridging the Digital Divide}

Technology access was an issue for a few educators in the study and many of their students. One educator described her technology struggles:

Reliable internet service would be a wonderful support during this time of distance learning. A way to solve this issue currently is to find a location with better reception for reliable service. I will carry my employee identification with me. If I am questioned about why I am not following shelter-in-place, I can justify being an essential employee teaching the future employees.

More often, educators described their students' technology issues. One educator reflected on wanting to use a Google Meet session to connect with students, particularly those struggling to complete assignments, but noted that "half of my students have requested paper packets and have limited internet." Another commented that

As we deal with distance learning due to COVID 19, I have realized that some students have technology available at home, but a few of them do not. Our district was very proactive in providing them with the tools they needed, but this took a few weeks. I had to get creative and make sure that they could do the work on paper. This meant texting pictures of the instructions to their parents, and them sending pictures of the completed work back to me via text. A student should not be excluded from learning because he/she does not have technology available during these difficult times.

Some educators described mailing letters home, texting, and phone calls to improve communication and foster relational bonds with students, particularly those who struggled with technology access. However, there was little personal or shared reflection on the digital divide apart from the evidence provided here. 


\section{Discussion}

Findings suggest that even among experienced educators who highly value student relationships, relationships may fall by the wayside as the school year progresses and standardsdriven curricular demands intensify. Further, even when educators strive to maintain relationships, there is a frustration that students' needs remain unmet, suggesting that some students do not perceive educators' care as such (Noddings, 2005). Remote learning provided an opportunity to reevaluate existing relationships and for educators to reinvest in building relational bonds with students through practicing authentic care.

Like Ginott (1972), who arrived at "the frightening conclusion that I am the decisive element in the classroom. It is my personal approach that creates the climate" (p. 13), educators quickly realized that their demeanor was crucial to their students' engagement in the remote environment. During the transition to remote learning, experienced educators in this study worked to (re)build relationships and serve as a "light" in students' lives. Guiding lights provide direction; they point airplanes to landing strips and ships to safe harbors. As guiding lights during COVID19 , educators tried to shepherd students to a sense of normalcy and connectedness by establishing a positive tone and insisting on high expectations, responding to students' non-academic needs, and encouraging peer interaction.

These findings complement existing research on caring in online learning communities. As warm demanders (Mastel-Smith et al., 2015; Vasquez, 1989; Ware, 2006), K-12 educators in this study positively set clear expectations and prioritized student success as their ultimate goal. They monitored students' completion of assignments and held students accountable for their behavior and time usage (Allen et al., 2018; Borup, Graham, et al., 2014). Similar to Velasquez, Graham, \& West's (2013) findings, educators expressed care by proactively reaching out to students, particularly those at risk of falling behind. Clarifying expectations on a one-to-one basis allowed educators to reinforce a shared purpose of student success and demonstrate to students that they were working on the "same side" (Kagan, Kyle, \& Scott, 2007) during a difficult time.

Educators in this study fostered teacher-student relationships by reprioritizing relationshipbuilding, learning about students' interests (Velasquez, Graham, \& West, 2013), listening closely to their students (Noddings, 2005; Osterman, 2010), and recognizing their non-academic needs (Baker et al., 1997). Educators employed various methods, including phone calls to students, physical letters home, and virtual office hours, to make personal connections with students and provide them with opportunities to share personal experiences. Educators' use of positive affirmations to highlight small successes and motivate students is also consistent with the literature on increasing student engagement online (Borup, West et al., 2014).

Educators used preferred technologies such as live chat to foster interaction (Velasquez, Graham, \& Osguthorpe, 2013). In line with Berry's (2019) recommended strategies, educators used synchronous class meetings to address academic content and provide outlets for personal sharing, in some cases allowing younger students to participate in virtual community circles. By responding to students' need for more informal synchronous peer interactions, educators helped foster the peer relationships vital to students' sense of school belonging (Peacock \& Cowan, 2019).

\section{Implications for Practice and Directions for Future Research}

Millions of children started the 2020-2021 school year remotely (Cleveland, 2020); it is clear that "school reopening during this global crisis is not a return to normal" (Giannini, Jenkins, 
\& Saavedra, 2020). As the United States faces continuing waves of COVID-19 infections, schools must contend with an uncertain future and the possibility of returning to remote learning full-time. Some districts may even define schooling's new normal as one that permanently blends face-toface and online modalities (Carter, 2020; Kluth, 2020). This study provides some direction for these considerations of schooling's "new normal."

\section{Relationships in Need of Repair}

Relationship-building was embedded in this graduate-level course as a classroom management strategy, but it was also a theme that course participants identified, pursued, and developed on their own. Participation in the course allowed educators to reflect collectively on how to engage students during remote learning; as such, the themes of the course and the shared reflection may have encouraged educators to foster relationships more than if they had not been taking the course. In some ways, the course served as a professional learning community, where educators were engaged in a critical and reflective interrogation of their teaching practice (Stoll et al., 2006).

Despite valuing a relational approach, educators in the study expressed the challenges of moving beyond simple rapport-building exercises to establish and sustain student relationships. School leaders can support educators' authentic care practices by modeling what caring relationships look like with their own teachers, who also need to experience belonging and school connectedness (Skaalvik \& Skaalvik, 2011), and by making relationships an institutional value. Findings presented here indicate these efforts may particularly benefit novice teachers, who may disproportionately struggle with relationship-building. Future research might investigate efforts schools and districts undertook to support and encourage educators during remote learning.

Schools and districts can also support educators by providing professional development on culturally responsive care. While the theme of educators acting as warm demanders emerged from the data analysis, the findings also suggest that educators had varying success bridging a cultural divide with their students. For some, the graduate course was the first time they had considered how their cultural backgrounds and experiences inform their teaching and expressions of care. In addition to professional development opportunities, school leaders can organize professional learning communities that investigate, discuss, and work to solve bias, prejudice, and poor teacherstudent relationships due to cultural mismatches and misunderstandings.

\section{Equitable Access to Belonging}

Building relationships remotely requires access to technology. Although educators incorporated analog communication methods, such as phone calls and mailed letters, the vast majority of their relationship-building efforts took place online through video meetings, chats, and discussions. Yet, low-income students disproportionately lacked access to necessary remote learning technology during remote learning (Basu, 2020; Herold, 2020). Considering that socioeconomically disadvantaged students are already more prone to experience isolation (OECD, 2019), future research might explore remote learning's effects on students' sense of belonging, particularly for those who could not fully access and engage in the online platform. In order to foster students' belongingness, and thus school success, schools, districts, and states must ensure all students have access to devices such as Chromebooks, internet connectivity, and a safe place to work so that educators can build inclusive remote learning communities where no student is left out because they lack the basic resources needed to participate. 


\section{Gathering More Perspectives}

This study focused on educators' perspectives and experiences as they attempted to create a caring space for teaching and learning during the pandemic. These experiences may be most relevant to teachers similar to those in this study: experienced educators pursuing an advanced degree in their field, who are interested in creating the best possible environment for teaching and learning. Further study with additional subgroups, such as novice teachers, and data sources, such as interviews, could help to triangulate findings and increase the generalizability of the results to a broader population.

In addition, while this study illuminates these educators' experiences of caring, it does not elucidate the receiving end of educators' efforts. Future research on students' perceptions during remote learning could provide insight into how they interpreted and experienced educators' expressions of care. Research on students' experiences of care would contribute to a more holistic understanding of online authentic care practices during the pandemic and could help inform schools' approach to community-building as districts, states, and countries consider new modes of schooling moving forward. 


\section{References}

Agee, J. (2009). Developing qualitative research questions: A reflective process. International Journal of Qualitative Studies in Education, 22(4), 431- 447. https://doi.org/10.1080/09518390902736512

Allen, K., Kern, M. L., Vella-Brodrick, D., Hattie, J., \& Waters, L. (2018). What schools need to know about fostering school belonging: A meta-analysis. Educational Psychology Review, 30, 1-34. http://doi.org/10.1007/s10648-016-9389-8

Ancess, J. (2008). Small alone is not enough: How can educators recover the purposes of small schools? Educational Leadership, 65(8), 48-53.

Anfara, V. A., Brown, K. M., \& Mangione, T. L. (2002). Qualitative analysis on stage: Making the research process more public. Educational Researcher, 31(7), 28-38. http://doi.org/10.3102/0013189X031007028

Antrop-González, R., \& De Jesús, A. (2006). Toward a theory of critical care in urban small school reform: Examining structures and pedagogies of caring in two Latino communitybased schools. International Journal of Qualitative Studies in Education, 19 (4), 409433. http://doi.org/10.1080/09518390600773148

Baker, J. A., Terry, T., Bridger, R., \& Winsor, A. (1997). Schools as caring communities: A relational approach to school reform. The School Psychology Review, 26(4), 586-602.

Basu, T. (2020, May 13). The children being left behind by America's online schooling. MIT Technology Review. https://www.technologyreview.com/2020/05/13/1001683/coronavirus-children-leftbehind-online-schooling/

Berry, S. (2019). Teaching to connect: Community-building strategies for the virtual classroom. Online Learning, 23(1). http://dx.doi.org/10.24059/olj.v23i1.1425

Borup, J., Graham, C. R., \& Velasquez, A. (2013). Technology-mediated caring: Building relationships between students and instructors in online K-12 learning environments. In M. Newberry, A. Gallant, \& P. Riley (Eds.), Emotions in school: Understanding how the hidden curriculum influences relationships, leadership, teaching, and learning (pp. 183202). EmeraldBooks.

Borup, J., Graham, C. R., \& Drysdale, J. S. (2014). The nature of teacher engagement at an online high school. British Journal of Educational Technology, 45(5), 793-806. http://doi.org/10.1111/bjet.12089

Borup, J., West, R. E., Graham, C. R., \& Davies, R. S. (2014). The adolescent community of engagement: A framework for research on adolescent online learning. Journal of Technology and Teacher Education, 22(1), 107-129.

Borup, J., \& Stevens, M. A. (2017). Using student voice to examine teacher practices at a cyber charter high school. British Journal of Educational Technology, 48(5), 1119-1130. http://doi.org/10.1111/bjet.12541

Borup, J., Walters, S., Call-Cummings, M. (2020) Student perceptions of their interactions with peers at a cyber charter high school. Online Learning, 24(2). http://dx.doi.org/10.24059/olj.v24i2.2015 
Bowen, G. A. (2009). Document analysis as a qualitative research method. Qualitative Research Journal, 9(2), 27-40. http://doi.org/10.3316/QRJ0902027

Carter, H. M. (2012). Institutionalization of caring in an era of accountability: Creating a supportive environment for at-risk students' retention in high school and access to college. The New Educator, 8(2), 177-193. http://doi.org/10.1080/1547688X.2012.670568

Carter, W. (2020, May 13). Dallas ISD may adopt hybrid learning plan, build new school campus devoted to partial at-home learning. NBCDFW. https://www.nbcdfw.com/news/local/carter-in-the-classroom/dallas-isd-may-adopthybrid-learning-plan-build-new-school-campus-devoted-to-partial-at-homelearning/2369014/

Cleary, P., Pierce, G., \& Trauth, E. (2005). Closing the digital divide: Understanding racial, ethnic, social class, gender and geographic disparities in Internet use among school age children in the United States. Universal Access in the Information Society, 4, 354-373.

Cleveland, C. (2020, August 10). Virtual fall: America's largest school districts are opting for remote starts. Education Next Blog. https:/www.educationnext.org/virtual-fall-americaslargest-school-districts-are-opting-for-remote-starts/\#plans

Cohen, J., McCabe, L., Michelli, N. M., \& Pickeral, T. (2009). School climate: Research, policy, practice, and teacher education. Teachers College Record, 111(1), 180-213.

Cooper, B. (2004). Empathy, interaction and caring: Teacher's roles in a constrained environment. Pastoral Care, 22(3), 12-21

Creswell, J. W. (2013). Qualitative inquiry and research design: Choosing among five approaches. SAGE Publications.

Davis, H. (2003). Conceptualizing the role and influence of student-teacher relationships on children's social and cognitive development. Educational Psychologist, 38(4), 207-234.

Dorn, E., Hancock, B., Sarakatsannis, J., \& Viruleg, E. (2020) COVID-19 and student learning in the United States: The hurt could last a lifetime. McKinsey \& Company. https://fresnostate.edu/kremen/about/centers-projects/weltycenter/documents/COVID-19and-student-learning-in-the-United-States-FINAL.pdf

Dreikurs, R., \& Cassel, P. (1972). Discipline without tears: A reassuring and practical guide to teaching your child positive behavior (1st ed.). Hawthorn Books.

Garrett Dikkers, A., Whiteside, A. L., \& Lewis, S. (2013). Virtual high school teacher and student reactions to the social presence model. Journal of Interactive Online Learning, $12(3), 156-170$.

Gay, G. (2018). Culturally responsive teaching: Theory, research and practice (3rd edition). Harvard University Press

Giannini, S., Jenkins, R., \& Saavedra, J., (2020). Reopening schools: When, where, and how? UNESCO. https://en.unesco.org/news/reopening-schools-when-where-and-how

Gilligan, C. (1993). In a different voice: Psychological theory and women's development. Harvard University Press. 
Ginott, H. G. (1972). Teacher and child: A book for parents and teachers (1st ed). Macmillan. Glassser, W. (1992). The quality school. HarperCollins Publishers.

Glasser, W. (1998). Choice theory in the classroom. HarperCollins Publishers.

Held, V. (2006). The ethics of care: Personal, political, and global. Oxford University Press.

Herold, B. (2020, April 10). The disparities in remote learning under coronavirus (in charts). Education Week. https://www.edweek.org/ew/articles/2020/04/10/the-disparities-inremote-learning-under-coronavirus.html

Jones, C. (2020, May 13). Student anxiety, depression increasing during school closures, survey finds. EdSource. https://edsource.org/2020/student-anxiety-depression-increasing-duringschool-closures-survey-finds/631224

Kagan, S., Kyle, P., \& Scott, S. (2007). Win-win discipline. Kagan Publishing.

Keyes, T. S. (2019). A qualitative inquiry: Factors that promote classroom belonging and engagement among high school students. School Community Journal, 29(1), 171-200.

Kluth, A. (2020, May 15) Your kids may never return to normal schooling. Bloomberg. https://www.bloomberg.com/opinion/articles/2020-05-15/coronavirus-your-kids-maynever-return-to-normal-schooling

Kotok, S., Ikoma, S., \& Bodovski, K. (2016). School climate and dropping out of school in the era of accountability. American Journal of Education, 122(4), 569-599.

Lewis, K., \& Pearce, S. (2020). High attaining students, marketisation and the absence of care: Everyday experiences in an urban academy. Pedagogy, Culture \& Society, 1-20.

Marshall, M. (2012). Discipline without stress, punishments, or rewards: How teachers and parents promote responsibility \& learning. Piper Press.

Maslow, A. H. (1962). Toward a psychology of being. D. Van Nostrand Company.

Mastel-Smith, B., Post, J., \& Lake, P. (2015). Online teaching: "Are you there, and do you care?" Journal of Nursing Education, 54(3), 145-151. https://doi.org/10.3928/0148483420150218-18

National Telecommunications and Information Administration (NTIA). (2014). Exploring the digital nation: Embracing the mobile Internet.

http://www.ntia.doc.gov/report/2014/exploring-digital-nation-embracing-mobile-internet

Noddings, N. (1984). Caring: A feminine approach to ethics and moral education.

University of California Press.

Noddings, N. (2002). Starting at home: Caring and social policy. University of California Press.

Noddings, N. (2003). Happiness and education. Cambridge University Press.

Noddings, N. (2005). The challenge to care in schools (2nd ed.). Teachers College Press.

Noddings, N. (2007). Caring as relation and virtue in teaching. In R. Walker \& P. Ivanhoe (Eds.),

Working virtue: Virtue ethics and contemporary moral problems (pp. 41-60). Oxford University Press. 
Noddings, N. (2012). The caring relation in teaching. Oxford Review of Education, 38(6), 771781.

OECD. (2017). PISA 2015 results (Volume III): Students' well-being. PISA, OECD Publishing. https://doi.org/10.1787/9789264273856-en

OECD. (2019). PISA 2018 results (Volume III): What school life means for students' lives. PISA, OECD Publishing. https://doi.org/10.1787/acd78851-en

Osterman, K. (2000). Students' need for belonging in the school community. Review of Educational Research, 70(3), 323-367. http://doi.org/10.3102/00346543070003323

Osterman, K. F. (2010). Teacher practice and students' sense of belonging. In T. Lovat, R. Toomey, \& N. Clement (Eds.), International research handbook on values education and student wellbeing (pp. 239-260). Springer. https://doi.org/10.1007/978-90-481-86754_15

Palloff, R. M., \& Pratt, K. (2007). Building online learning communities: Effective strategies for the virtual classroom. John Wiley \& Sons.

Pang, V. O., Rivera, J., \& Mora, J. K. (2000). The ethic of caring: Clarifying the foundation of multicultural education. The Educational Forum, 64(1), 25-32. http://doi.org10.1080/00131729908984722

Peacock, S., \& Cowan, J. (2019) Promoting a sense of belonging in online learning communities of inquiry. Online Learning, 23(2). http://dx.doi.org/10.24059/olj.v23i2.1488

Ransom, J. C. (2020). Love, trust, and camaraderie: Teachers' perspectives of care in an urban high school. Education and Urban Society, 52(6), 904-926.

Resnick, M., Bearman, P. S., Blum, R. W., Bauman, K. E., Harris, K. M., Jones, J., Tabor, J., Beuhring, T., Sieving, R. E., Shew, M., Ireland, M., Bearinger, L. H., \& Udry, J. R. (1997). Protecting adolescents from harm. JAMA, 278(10), 823-832.

Resta, P., Laferrière, T., McLaughlin, R., \& Kouraogo, A. (2018). Issues and challenges related to digital equity: An overview. Second handbook of information technology in primary and secondary education. Springer.

Riley, K. (2019). Agency and belonging: What transformative actions can schools take to help create a sense of place and belonging? Educational \& Child Psychology, 36(4), 91-103.

Ritzhaupt, A. D., Liu, F., Dawson, K., \& Barron, A. E. (2013). Differences in student information and communication technology literacy based on socio-economic status, ethnicity, and gender: Evidence of a digital divide in Florida schools. Journal of Research on Technology in Education, 45(4), 291-307. https://doi.org/10.1080/15391523.2013.10782607

Robinson, H. A., Kilgore, W., Warren, Scott J. (2017). Care, communication, support: Core for designing meaningful online collaborative learning. Online Learning, 21(4). http://dx.doi.org/10.24059/olj.v21i4.1240.

Ryan, G. W., \& Bernard, H. R. (2003). Techniques to identify themes. Field Methods, 15(1), 85109. http://doi.org/10.1177/1525822X02239569 
Skaalvik, E. M., \& Skaalvik, S. (2011). Teacher job satisfaction and motivation to leave the teaching profession: Relations with school context, feeling of belonging, and emotional exhaustion. Teaching and Teacher Education, 27(6), 1029-1038. https://doi.org/10.1016/j.tate.2011.04.001

St-Amand, J., Girard, S., \& Smith, J. (2017). Sense of belonging at school: Defining attributes, determinants, and sustaining strategies. IAFOR Journal of Education, 5(2), 105-119.

Stoll, L., Bolam, R., McMahon, A., Wallace, M., \& Thomas, S. (2006). Professional learning communities: A review of the literature. Journal of Educational Change, 7(4), 221-258.

Tichnor-Wagner, A., \& Allen, D. (2016). Accountable for care: Cultivating caring school communities in urban high schools. Leadership and Policy in Schools, 15(4), 406-447

Vaismoradi, M., Jones, J., Turunen, H., \& Snelgrove, S. (2016). Theme development in qualitative content analysis and thematic analysis. Journal of Nursing Education and Practice, 6(5), 100-110. http://dx.doi.org/10.5430/jnep.v6n5p100

Valenzuela, A. (1999). Subtractive schooling: Issues of caring in education of US-Mexican youth. State University of New York Press.

Vasquez, J. (1989). Contexts of learning for minority students. The Education Forum, $52(3), 243-253$.

Velasquez, A., Graham, C. R., \& Osguthorpe, R. (2013). Caring in a technology-mediated online high school context. Distance Education, 34(1), 97-118. https://doi.org/10.1080/01587919.2013.770435

Velasquez, A., Graham, C. R., \& West, R. E. (2013). An investigation of practices and tools that enabled technology-mediated caring in an online high school. The International Review of Research in Open and Distance Learning, 14(5), 277-299. http://www.irrodl.org/index.php/irrodl/article/view/1465/2758

Wang, M., \& Eccles, J. (2012). Social support matters: Longitudinal effects of social support on three dimensions of school engagement from middle to high school. Child Development, 83(3), 877-895, http://dx.doi.org/10.1111/j.1467-8624.2012.01745.x

Ware, F. (2006). Warm demander pedagogy: Culturally responsive teaching that supports a culture of achievement for African American students. Urban Education, 41(4), 427-456. 